\title{
PCDD/F, PBDE, and nonylphenol contamination in a semi-enclosed bay (Masan Bay, South Korea) and a Mediterranean lagoon (Thau, France)
}

\author{
Sang Hee Hong ${ }^{a}$, Catherine Munschy ${ }^{b}$, Narayanan Kannan ${ }^{a}$, Celine Tixier $^{b}$, Jacek \\ Tronczynski $^{\mathrm{b}}$, Karine Héas-Moisan ${ }^{\mathrm{b}}$ and Won Joon Shim ${ }^{\mathrm{a},{ }^{*}}$
}

\begin{abstract}
a Oil and POPs Research Group, Korea Ocean Research and Development Institute, 391 Jangmok-ri, Jangmokmyon, Geoje-shi 656-834, Republic of Korea

${ }^{b}$ Institut Français de Recherche pour l'Exploitation de la Mer (IFREMER), Laboratory of Biogeochemistry of Organic Contaminants, BP 21105, 44311 Nantes Cedex 3, France
\end{abstract}

*: Corresponding author: Won Joon Shim, Tel.: +82 55639 8671; fax: +82 556398689 , email address : wjshim@kordi.re.kr

\begin{abstract}
:
Chemical contamination of the coastal marine environment by polychlorinated dibenzo- $p$-dioxins (PCDDs) and polychlorinated dibenzofurans (PCDFs) was assessed along with emerging contaminants such as polybrominated diphenyl ethers (PBDEs) in an industrially well-developed country (France) and a fast-developing country (Korea). Other chemicals, i.e. nonylphenol (NP) and 5 $\beta(\mathrm{H})$-cholestan-3 $\beta$-ol (coprostanol) were determined to trace industrial waste and/or domestic inputs. These compounds were analyzed in coastal sediments and mussels in two enclosed coastal water bodies: Masan Bay (South Korea) and Thau lagoon (France). The overall levels of target organic contaminants were higher in Masan Bay than in Thau lagoon. The mean concentrations of 17 PCDD/Fs, 13 PBDEs, NP and coprostanol in Masan Bay sediments were, respectively, 1.3, 11,248 and $291 \mathrm{ng} \mathrm{g}^{-1}$ dry weight (d.w.); in Thau lagoon sediments they were, respectively, 0.39, not detectable (nd), 23 and $395 \mathrm{ng} \mathrm{g}^{-1} \mathrm{~d} . \mathrm{w}$. Mean concentrations in mussels (coprostanol and cholestanol were not measured) were 0.0093, 13, $140 \mathrm{ng} \mathrm{g}^{-1} \mathrm{~d} . \mathrm{w}$. in Masan Bay and 0.016, 0.94, $38 \mathrm{ng} \mathrm{g}^{-1} \mathrm{~d} . \mathrm{w}$. in Thau lagoon. Principal component analysis of the contaminants and chemical tracers indicates possible point sources of pollution for Masan Bay and Thau lagoon. This study highlights a growing pollution problem in Asia and in particular a tremendous uptrend in Korea, in comparison to more controlled discharges and releases in Western Europe.
\end{abstract}

Keywords: Marine environment; Sediment; Mussel; Organohalogen contaminant; Waste chemical tracer 


\section{Introduction}

KORDI (Korea Ocean Research and Development Institute) and IFREMER (French Research Institute for Exploitation of the Sea) conducted a joint research project on the current status of marine coastal environmental pollution in both countries under the 'Science and Technology Amicable Relationship (STAR)' program.

The aim of this joint study was to evaluate and compare the status and characteristics of persistent organic chemical contamination in coastal areas of France and Korea. Historical contaminants such as polychlorinated dibenzo-p-dioxins (PCDDs), polychlorinated dibenzofurans (PCDFs) and emerging pollutants such as polybrominated diphenyl ethers (PBDEs) were studied in two enclosed water bodies: Masan Bay in Korea and Thau lagoon in France. PBDEs are of great concern in Asia (Martin et al. 2004) and in particular in Korea, whose economy depends heavily on industries such as computers, home appliances, textiles and automobiles, the manufacture of which involves the use of brominated flame retardants. From a global perspective, Korea consumes more than $10 \%$ of the total production of flame retardants and the observable trend indicates that this figure will not decrease in the near future (Jang et al. 2001, Moon et al. 2007a).

In addition to historical and emerging contaminants, nonylphenol (NP) and sterols were also determined in the samples collected in both countries. NP was studied as a sewage/industrial wastewater tracer, whereas $5 \beta(\mathrm{H})$-cholestan-3 $\beta$-ol (coprostanol) was studied as a typical marker of sewage pollution. Studies have shown that coprostanol cannot, unambiguously, be attributed alone to faecal pollution, as the diagenetic degradation of sterols in anoxic environments may also give rise to coprostanol. Hence, in order to standardize the effect of the natural production of coprostanol in the environment, a sterol ratio was proposed by Grimalt et al. (1990) i.e., $\mathrm{C}_{\text {coprostanol }}$ 
$/\left(\mathrm{C}_{\text {cholestanol }}+\mathrm{C}_{\text {coprostanol }}\right)[5 \beta /(5 \alpha+5 \beta)]$. In order to fine-tune this index, $5 \alpha(\mathrm{H})$-cholestan-3 $3-\mathrm{ol}$ (cholestanol) was determined in sediment samples. Application of this index is explained further on. Interestingly, NP is a pollutant on its own respect. It is a very potent endocrine, disrupting chemical and degradation product of non-ionic surfactant, alkylphenol polyethoxylates entering aquatic environments via industrial and municipal wastewater discharges due to their widespread usage in cleaning products and industrial processes (Giger et al., 1984; Rice et al., 2003; Cheng et al., 2006).

This study enabled us to evaluate the pollution status of partially-enclosed coastal water bodies in two world locations with different pollution sources and lifestyles. Moreover, France is recognized as a developed country, whereas Korea is in the process of becoming a fullydeveloped country. Industrialization began in Korea in the late 1960s, incurring massive economic, social and political transformations. Industrialization started on the south-eastern shores, where ports suitable for worldwide trading already existed. Among the region's various heavily-industrialized and rapidly-urbanized bays, Masan Bay is one of the largest. Masan Bay has already been the focus of many studies on pollution, mainly by organotins, alkylphenols, organochlorine pesticides, polychlorinated biphenyls (PCBs), polycyclic aromatic hydrocarbons (PAHs), PCDDs and PCDFs (Shim et al. 1999; Khim et al., 1999; Hong et al., 2003; Im et al., 2002; Yim et al., 2005; Kannan et al., 2007). Thau lagoon is one of the largest Mediterranean lagoons, located in the South of France on the Mediterranean coast. This lagoon receives inputs from various anthropogenic sources, i.e. urban, industrial, agricultural and shellfish farming activities. Previous surveys indicate that sediments are highly contaminated by PAHs and, to a lesser extent, by PCBs, compared to other Mediterranean lagoons (Castro-Jimenez et al., 2008, Léauté, 2008). 
This paper highlights the outcome of our joint study, involving measurements of PCDD/Fs, PBDEs, NP, coprostanol and cholestanol. The results presented here provide new data and are of particular relevance in view of the lack of environmental data on PBDEs, especially in Asia (Martin et al., 2004).

\section{Materials and methods}

\subsection{Sampling}

Masan Bay is a semi-enclosed bay situated in the southern area of Korea (Fig. 1a). This bay is surrounded by heavily-populated cities and industrial complexes discharging significant amounts of organic pollutants into the bay. Masan Bay is bordered by the heavily-populated cities of Masan, Changwon and Chinhae; several industrial complexes comprising petrochemical, heavy metal, electrical, and plastic factories discharge significant amounts of organic pollutants directly into the bay. Discharges from a municipal sewage treatment plant also enter the bay close to sampling site S12/M12. The semi-enclosed nature of the bay, its very weak currents $(2-3 \mathrm{~cm} / \mathrm{s})$ and the long residence time of water $(10-12 \mathrm{~h})$ inside the inner bay lead to accumulation of pollutants in water and sediment.

Thau lagoon covers a surface area of $75 \mathrm{~km}^{2}$, with an average depth of 4-5 $\mathrm{m}$ and a maximum depth of $11 \mathrm{~m}$. Its catchments area covers $250 \mathrm{~km}^{2}$. The lagoon is isolated from the Mediterranean Sea by an offshore barrier and is connected to the sea by two channels (Fig. 1b). Tidal amplitudes are commonly weak in the Mediterranean. However, the renewal rate of water inside the lagoon is still substantial, with up to $12 \%$ of the water mass exchanged within 3 days (Souchu et al., 1997). The lagoon receives inputs from various human activities, i.e. urban activities, industries (cement, fertilizer and wine production plants), port activities and 
agriculture (crops and vineyards). The majority of urban, industrial and port activities are situated near the city of Sète in the Eastern part of the lagoon. Fishing, fish farming and shellfish farming, the latter covering about $20 \%$ of the total area of the lagoon, are other major regional industries. This lagoon is highly contaminated by organic contaminants compared to other Mediterranean lagoons (Castro-Jimenez et al., 2008).

Mussel (Mytilus galloprovincialis) and sediment samples were collected from Thau lagoon, France in May 2004, and from Masan Bay, Korea, in May 2006 (Fig. 1a and 1b). Surface sediment samples were collected using a van Veen grab sampler (Masan Bay samples) and using a sediment corer (Thau lagoon samples). In both cases, sub-samples of upper $2 \mathrm{~cm}$ sediment were collected with a stainless steel spatula for further analysis. Mussels were collected manually in both bays and depurated at room temperature for 24 hours before further treatment. This allowed a natural removal of gut content from the mussels, hence facilitating an accurate assessment of contaminant concentrations in soft tissues. Each sample comprised at least 60 individuals of uniform size $(45-55 \mathrm{~mm})$. The mussels were shucked, crushed and homogenized with a blender, then stored at $-20{ }^{\circ} \mathrm{C}$. Both sediment and mussel samples were freeze-dried and transported for analysis to the respective laboratories in France and Korea. PCDD/Fs and PBDEs in mussels and sediments were analysed at IFREMER in France, while the other contaminants were analysed at KORDI in Korea.

\subsection{Chemical analyses}

$\mathrm{PCDD} / \mathrm{F}$ and $\mathrm{PBDE}$ analysis

The analytical protocols for extraction and cleanup of PCDD/Fs and PBDEs have been described elsewhere (Johansson et al., 2006; Munschy et al., 2008). The analytical procedure 
consists of extraction of $5 \mathrm{~g}$ dry weight (d.w.) of mussel flesh and $7 \mathrm{~g}$ d.w. of sediment using pressurized solvent extraction (ASE, Dionex Corp., USA), followed by gel permeation chromatography on Bio-Beads S-X3 (200-400 mesh) (mussel samples) or removal of sulphur with activated copper (sediment samples), and fractionation on silica and alumina columns, then on a two-dimensional high-performance liquid chromatography system. Quantification of the seventeen $\mathrm{PCDD} / \mathrm{F}$ congeners substituted in $2,3,7,8$ positions was based on the isotopic dilution method stipulated by US EPA method 1613, and was done using High Resolution Gas Chromatography - High Resolution Mass Spectrometry (HRGC-HRMS) with an AutoSpec Ultima (Waters), equipped with an RTX-Dioxin2 (Restek Corp., USA) capillary column (40 m x $0.18 \mathrm{~mm} \times 0.18 \mu \mathrm{m}$ film thickness).

PBDE congeners, namely BDE-28, $-47,-49,-66,-77,-85,-99,-100,-138,-153,-154,-183$ and -209 were analyzed following the method described by Johansson et al. (2006), using an Agilent 6890 series gas chromatograph coupled to an Agilent 5973 quadropole mass spectrometer in electron capture negative ionisation mode (ECNI) using methane as the reagent gas. 1- $\mu \mathrm{L}$ injections were made in the on-column mode and the injector was programmed to track oven temperature. Determination of all PBDEs except BDE-209 was achieved using a DB5-MS (40 m x $180 \mu \mathrm{m}$ (i.d.) x $0.18-\mu \mathrm{m}$ film thickness) fused-silica capillary column (J\&W Scientific, USA). The GC oven temperature program was as follows: isothermal at $60{ }^{\circ} \mathrm{C}$ for one $\mathrm{min}, 40{ }^{\circ} \mathrm{C} / \mathrm{min}$ to $180{ }^{\circ} \mathrm{C}, 15{ }^{\circ} \mathrm{C} / \mathrm{min}$ to $240{ }^{\circ} \mathrm{C}, 4{ }^{\circ} \mathrm{C} / \mathrm{min}$ to $305{ }^{\circ} \mathrm{C}$, then held at $305{ }^{\circ} \mathrm{C}$ for $2 \mathrm{~min}$. A shorter column was used for BDE-209: a DB-1 (15 m x $250 \mu \mathrm{m} \times 0.10 \mu \mathrm{m}$ film thickness) (J\&W Scientific, USA), using the following temperature program: $70{ }^{\circ} \mathrm{C}$ for $1.5 \mathrm{~min}, 40{ }^{\circ} \mathrm{C} / \mathrm{min}$ to $175^{\circ} \mathrm{C}, 10^{\circ} \mathrm{C} / \mathrm{min}$ to $250{ }^{\circ} \mathrm{C}, 50{ }^{\circ} \mathrm{C} / \mathrm{min}$ to $320^{\circ} \mathrm{C}$, then held at $320^{\circ} \mathrm{C}$ for $3 \mathrm{~min}$. The GC to MS transfer line was held at $280{ }^{\circ} \mathrm{C}$ and the ion source temperature was set to $210{ }^{\circ} \mathrm{C}$. Selected ion 
monitoring of the two bromide ions at m/z 79 and 81 was used to detect all PBDEs except BDE209, for which 486 and 488 ions were monitored. Quantification was done by external calibration. BDE-190 was used as an internal (injection) reference standard, and BDE-139 was used as the surrogate (recovery) standard.

Nonylphenol (NP) was analyzed in sediment and mussel samples according to the methods of Li et al. (2003 and 2008). Briefly, about $3 \mathrm{~g}$ of sediment (wet) was placed in a $50 \mathrm{~mL}$ Teflon centrifuge tube with a Teflon cap. After the addition of $5 \mathrm{~mL}$ of $0.1 \mathrm{M} \mathrm{HCl}$ solution, the sediment samples were extracted with dichloromethane (DCM). $5 \mathrm{~g}$ of freeze-dried mussel was extracted with DCM using Soxhlet apparatus for 16 hours. Surrogate standards (heptylphenol and bisphenol A-d14) were added before extraction. Micro concentration and solvent exchange followed by derivatization (BSTFA (N,O-bis (trimethylsilyl) trifluoroacetamide) were performed for both samples. In the case of sediment, activated copper was added to remove sulphur, followed by $\mathrm{Na}_{2} \mathrm{SO}_{4}$ (anhydrous) to remove water before derivatization. After this, samples were placed on a florisil column and eluted with hexane. The concentrated eluents were analyzed by gas chromatography (Shimadzu GC 2010)-mass spectrometry (Shimadzu MS 2010) with selected ion monitoring mode after addition of $200 \mathrm{ng}$ of GCIS. Conditions for GC/MS analysis have been described in previous reports (Li et al., 2001).

In order to determine the concentrations of coprostanol and cholestanol, a $1 \mathrm{~g}$ dry sample was extracted using the pressurized solvent extraction (ASE 200 A, Dionex Corp, USA) technique with dichloromethane ( $\mathrm{Li}$ et al., 2007). Prior to extraction, $5 \alpha$-androstan-3 $\beta$-ol was added for monitoring recovery of coprostanol and cholestanol. Briefly, sediment samples were ground and placed in a $33 \mathrm{ml}$ stainless steel cell. Before loading the sample, a cellulose filter and $\mathrm{Na}_{2} \mathrm{SO}_{4}$ (anhydrous) were packed in the cell. The extraction was carried out at $120^{\circ} \mathrm{C}$ and $1500 \mathrm{psi}$. Static 
and extraction times were 5 and 15 mins. respectively. Compressed nitrogen gas was used to purge the extract and solvent into the corresponding vial. Dichloromethane was used as an extracting solvent. The processes including concentration, silyl derivatization and clean-up steps were similar to phenolic compounds analysis. Coprostanol and cholestanol were analyzed on the same GC/MS system used for the phenolic analytes, with different final temperature and fragment ions.

\subsection{Quality Assurance / Quality Control}

The quality assurance/quality control (QA/QC) procedures described below apply to all target chemicals including analyses of blanks, replicate samples, standard reference materials, and use of spiked internal standards. For PBDE and PCDD/F analyses, for which external contamination could be the most problematic, samples were processed in the laboratory in a clean, low-dust atmosphere, under positive pressure. Recovery standards were added at the beginning of the procedure and pursued throughout the extraction, cleanup, and instrumental analysis steps in order to determine recovery of the procedure as a whole. The following, specific quality assurance steps were used to ensure measurement accuracy and precision: one procedural blank, one matrix spike, one duplicate sample and one standard reference material were run with each batch of up to 20 samples. Blanks were generally uncontaminated by the study compounds, apart from BDE-209 which was the most frequently detected compound, but at low levels (i.e. usually

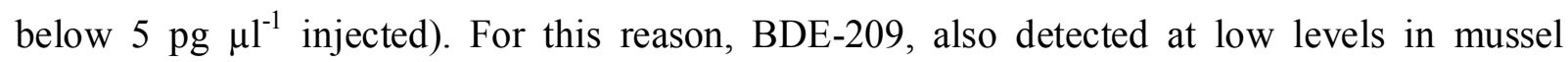
samples, was not reported for biota. Conversely, BDE-209 levels in sediments were far higher than levels detected in the blanks.

The French laboratory routinely participates in the QUASIMEME (Quality Assurance of 
Information for Marine Environmental Monitoring in Europe) inter-comparison exercises for PCDD/Fs and PBDEs in mussels and fish, and Z scores are generally found to be within the satisfactory range. Similarly, the Korean laboratory takes part in inter-laboratory exercises on persistent organic chemicals with satisfactory results.

Analyses of reference materials were incorporated in our sample analyses and used to monitor overall method accuracy. The material used for biota was WMF-01 (Wellington laboratories, Canada), a freeze-dried fish tissue containing certified reference values for BDE congeners 28 , $47,99,100,153154$ and 183 , and certified or information values for the $172,3,7,8-\mathrm{PCDD} / \mathrm{F}$ congeners. WMS-O1 (Wellington laboratories, Canada), a freeze-dried sediment providing certified values for 2,3,7,8 PCDD/Fs, except 1,2,3,7,8,9-hexachlorodibenzofuran for which only an indicative value was assigned, was also used for QA/QC. Unfortunately, no reference sediment was commercially available for PBDEs at the time of this study. Hence, the laboratory used sediments provided by QUASIMEME as reference samples.

\section{Results and discussion}

\subsection{Levels}

Detailed concentrations of PCDDs, PCDFs, PBDEs, NP, coprostanol and cholestanol are shown in Table 1 for sediments and in Table 2 for mussels. As coprostanol and cholestanol are biological molecular markers useful for determining sources of sewage pollution, they are typically measured in sediments and not in mussels. Generally speaking, study contaminant levels in Masan Bay samples were higher than those in Thau Lagoon samples. For example, average concentrations (Masan Bay: $n=5$; Thau Lagoon: $n=6)\left(n g g^{-1}\right.$ dry weight d.w.) of the 17 PCDD/Fs, 13 PBDEs, NP, coprostanol and cholestanol in Masan Bay sediments were 1.3, 11, 
248, 291 and $482 \mathrm{ng} \mathrm{g}^{-1}$ d.w. respectively. Values for Thau Lagoon sediments were 0.39, not detectable (nd), 23, 395 and $4450 \mathrm{ng} \mathrm{g}^{-1}$ d.w.. The average concentrations of 17 PCDD/Fs, 12 PBDEs (BDE 209 excluded) and NP determined in Masan Bay mussels were 0.0092, 13, and $140 \mathrm{ng} \mathrm{g}^{-1}$ d.w., while levels were $0.016,0.92$ and $38 \mathrm{ng} \mathrm{g}^{-1} \mathrm{~d}$.w. in Thau lagoon.

\subsection{1. $\mathrm{PCDD} / \mathrm{Fs}$}

The summed concentrations of PCDD/Fs in sediments at most sites were at least three times higher in Masan Bay (1.35 $\mathrm{ng} \mathrm{g}^{-1}$ d.w.) than in Thau lagoon $\left(0.47 \mathrm{ng} \mathrm{g}^{-1}\right.$ d.w. $)$. PCDD/F concentrations in sediments from Masan Bay were higher than those found in other industrialized areas such as Yeongil, Ulsan, Busan and Gwangyang bays in Korea, or Qindao, China (Koh et al., 2004; Moon et al., 2008; Pan et al., 2008), while the levels in Hong Kong sediments were higher than those in Korea (Kueh et al., 2008). PCDD/F concentrations in Thau lagoon sediments were in the range of those found in Venice lagoon, except at site TS12, where concentrations were higher but remained far below the maximum concentrations found in Venice channels directly impacted by industries (Dalla Valle et al., 2003). Thau lagoon PCDD/F concentrations in sediment were generally low except at site TS12, and within the range found in remote marine and lake sediments (Isosaari et al., 2002).

The spatial distribution of PCDD/Fs in Masan Bay indicated that the inner part of the bay was more contaminated than the outer part, except at site S12 where a municipal sewage outlet is located, and where the highest levels for PCDD/Fs were found (4.68 $\mathrm{ng} \mathrm{g}^{-1}$ d.w.). Moon et al. (2009) reported that PCDD/F concentrations observed in a sediment core collected adjacent to the Masan Bay sewage treatment plant were one order of magnitude higher than in an inner bay sediment core (sample). Similarly high concentrations of PCDD/Fs in sediment have also been 
reported in the vicinity of a sewage treatment plant in Hyengsan River, Korea (Koh et al., 2004). In Thau lagoon, the highest concentrations of PCDD/Fs were found at site TS12 (1.66 ng g ${ }^{-1}$ d.w.) in the Eastern part of the lagoon, and the lowest concentrations at site TS2, located in the Western part. This suggests that main sources of contamination by PCDD/Fs are situated in the Eastern part of the lagoon, where its main urban and industrial activities are located.

Moreover, PCDD concentrations at most sites in both Korea and France were found to be higher than PCDF concentrations. However, PCDF levels at site S12 in Masan Bay were approximately two times higher than PCDD levels. This implies that sewage discharges, carrying both domestic and industrial wastes, constitute a point source. Kannan et al. (2007) underlined the fact that the chemical, electrical and steel industries that have developed along the shores of Masan Bay could all have contributed to $\mathrm{PCDD} / \mathrm{F}$ inputs into the bay. A recent publication on the historical trends of PCDD/DFs in Masan Bay stressed that PCDD/F concentrations and fluxes have rapidly increased since the opening of the waste water treatment plant (WWTP), indicating that WWTP discharges are a major source of sediment contamination in the bay (Moon et al., 2009). In addition, processes such as municipal and chemical waste incineration (including uncontrolled trash burning), hospital waste incineration and other combustion processes may result in the production of a range of PCDD/PCDF isomers in Masan Bay sediments. All these factors, coupled with a quest to increase the country's productivity, may have contributed to the recent increase in PCDD/Fs in Masan Bay. Conversely, PCDD/F emissions in mainland France have dropped drastically in recent years, decreasing by a factor of three between 1995 and 2000 (CITEPA, 2007). In response to regulations relating to emissions, a general downtrend in PCDD/Fs in mussels has also been observed on French coasts (Munschy et al., 2008).

Interestingly, $\mathrm{PCDD} / \mathrm{F}$ concentrations in Thau lagoon mussels were slightly higher $(\mathrm{PCDFs}=1.3$ 
times; PCDDs=2.1 times) than in Masan Bay mussels (Table 2). The highest concentration (21.4 pg $\mathrm{g}^{-1}$ d.w.) was found at site TM1 in the Western part of Thau lagoon, whereas the highest concentration (14.6 $\mathrm{pg} \mathrm{g}^{-1}$ d.w.) in Masan Bay was found in the inner bay. While PCDDs and PCDFs showed similar levels in mussels from Masan Bay, the concentrations of PCDDs were higher than those of PCDFs in mussels from Thau lagoon, mainly due to OCDD contributions. When results were expressed in WHO-TEQ (Toxic Equivalent), TEQ concentrations at both sites were shown to be below the maximum level set by the European Commission (EC) for fishery products intended for human consumption, which is $4 \mathrm{pg} \mathrm{WHO}_{2005}$-TEQ $\mathrm{g}^{-1}$ ww (EC No 199/2006). The concentrations reported here for Thau lagoon samples (0.075-0.27 pg g $^{-1}$ w.w.) were in the lower range of those reported for mussels collected in 2004 and 2005 along French coasts (Munschy et al., 2008). They were also in the lower range of concentrations reported in other European countries (Bayarri et al., 2001; Knutzen et al., 2003; Bordajandi et al., 2006; Caixach et al., 2007) and in Asia (Moon et al. 2006, Hashimoto et al. 1999, Oh et al. 2003). However, an earlier Masan Bay oyster study reported a higher average level of $9.2 \mathrm{pg} \mathrm{g}^{-1} \mathrm{ww}$ (Hashimoto et al. 1998).

\subsubsection{PBDEs}

PBDE concentrations in sediments are presented in Table 1 . No detectable $\left(<10\right.$ to $100 \mathrm{pg} \mathrm{g}^{-1}$ d.w. related to congener) residues of these compounds were found in Thau Lagoon sediments. Conversely, in Masan bay, residues were detected from 3.5 to $25 \mathrm{ng} \mathrm{g}^{-1}$ d.w., with a mean value of $11 \mathrm{ng} \mathrm{g}^{-1} \mathrm{~d}$.w. (sum of the 13 congeners), the predominant congener being BDE-209.

Concentrations of these chemicals in sediments was several orders of magnitude higher in Masan Bay than in Thau lagoon, reflecting the country's industrial growth and increasing 
demand for manufactured products. However, PBDE concentrations in sediments from Masan Bay were lower than the maximum levels reported on Korean coasts by Moon et al. (2007a), and in comparison to those reported in Japan, Hong Kong and the US (Ohta et al., 2002; Liu et al., 2005; Oros et al., 2005).

Nonetheless, PBDEs were found in all mussel samples from Thau Lagoon, although at relatively low concentrations, e.g. 0.63 to $1.44 \mathrm{ng} \mathrm{g}^{-1}$ d.w. (mean value $1.03 \mathrm{ng} \mathrm{g}^{-1}$ d.w for the sum of 12 congeners, $n=3$ ). The levels in Masan Bay mussels were at least 10 times higher, with concentrations ranging from 1.38 to $27.3 \mathrm{ng} \mathrm{g}^{-1}$ d.w (mean value $12.9 \mathrm{ng} \mathrm{g}^{-1}$ d.w., $\mathrm{n}=5$ ). The contamination of mussels by PBDEs has been studied previously in Thau lagoon; the data reported here complies with previous data obtained by the same IFREMER team (Johansson et al., 2006). As reported in Johansson's paper, Thau lagoon was one of the least contaminated sites studied along France's coasts (Atlantic, English Channel, and Mediterranean). In comparison to data collected in other areas of the world, mussels from Thau lagoon show low contamination by PBDEs. Although the number of analysed PBDE congeners differed, the concentrations reported in Europe, i.e. Greenland, Norway, Belgium and the Netherlands were in the 0.06 to $28 \mathrm{ng} \mathrm{g}^{-1}$ d.w. range (Moon et al., 2007a). BDE-47, which is reported as being the predominant congener in mussels, was much higher in samples from the US and Brazil (refs in Johansson et al., 2006). Levels in Masan Bay mussels appear to be lower than in Hong Kong (Liu et al., 2005), Pearl River-China (Mai et al., 2005) and Osaka Bay-Japan (Ohta et al., 2002), but higher than levels on the Yellow Sea coast of China (Bohai) (Wang et al., 2009).

\subsection{Congener patterns of PCDD/Fs and PBDEs}

The isomer composition of PCDDs and PCDFs showed differences when the two matrices 
were compared, while the average pattern was similar between regions using the same matrix (Fig. 2). The average pattern in sediment in both regions was clearly dominated by OCDD, followed by $1,2,3,4,6,7,8-\mathrm{HpCDD}, 1,2,3,4,6,7,8-\mathrm{HpCDF}$, and OCDF (Fig. 2). OCDD was found to be the predominant congener in deposits on a worldwide scale (Brzuzy and Hites, 1996), attributed to the production and use of PCP and to the photochemical synthesis of pentachlorophenol (PCP) in the atmosphere (Baker and Hites, 2000). OCDD predominates in the majority of sources (Zhu et al., 2008), which are mainly combustion processes (MacDonald et al., 1998). Although the congener profiles found in sediment could result from mixed sources, the pattern observed, which was dominated by hepta- and octa-CDDs, could well be linked to pentachlorophenol-related inputs (Hassanin et al., 2006). In a recent publication on sediment cores, Moon et al. (2009) concluded that pre-1994 samples, i.e. prior to the WWTP in Masan Bay, invariably reflected PCP and chloronitrofen (CNP) usage.

A principal component analysis on the composition of individual PCDD/F congeners was attempted (Fig. 3). Three principal components (PCs) with eigenvalues above one were chosen, explaining $88 \%$ of total variation. PC1 opposes OCDD to the other congeners, while PC2 opposes high chlorinated PCDFs (hexa-, hepta- and octa) to the other congeners (Fig. 3). Three groupings are visible in Masan Bay sediments: the sewage outlet site (S12), the inner bay sites (S5 and S8) and the outer bay sites (S20, S21). The singular pattern observed at site S12 is linked to high inputs of OCDF, hexa- and hepta-CDFs. A similar observation was made recently by Kannan et al. (2007) and Moon et al. (2009) on sediments from Masan Bay.

The isomeric composition of sediment was found to differ from that of mussels, in which 2,3,7,8-TCDF and OCDD are the dominant congeners (Fig. 2). This observation appears to be typical of mussels and corresponds to previous observations in other marine areas (Abad et al., 
2003 Munschy et al. 2008).

The congener composition of PBDEs in Masan Bay sediment was dominated by BDE-209 (Table 1), owing to the fact that the commercially-available PBDE flame retardant used in Korea is largely the deca-mix PBDE formulation (Cischem, 2005). In both Asia and Europe, the decamix formulation is currently used in greater volumes than the octa-mix and penta-mix formulations (Law et al., 2006). BDE-209 is generally identified as the predominant congener in sediments, as it is highly hydrophobic and tends to adsorb to particulate matter. This congener has also previously been reported as the main congener in atmospheric deposits in Korea (Moon et al. 2007b). Its levels have increased exponentially since 1990 in response to increasing demand for decaBDE products for electronic goods manufacture in Asia, and in particular in China (Law et al., 2008). The predominant congeners in mussels were tetra- and pentabrominated BDEs (BDE-47, -99 and -100) in both Masan Bay and Thau lagoon (Table 2). This pattern was also reported in an earlier study on mussel samples from coastal areas in Korea (Kannan et al., 2005), and in studies on biological samples worldwide (Wang et al., 2008). BDE209 levels were not found to be significantly different from those of the blanks, probably because this congener does not accumulate easily in organisms (Kierkegaard et al., 1999; Booij et al., 2002). Some authors have reported BDE-209 in mussels, but this is generally thought to be owed to a failure to depurate mussels before analysis, in which case BDE-209 may be found in the gut or mantle (Moon et al. 2007a; Ramu et al., 2007).

\subsection{Chemical tracers used in source identification}

Three additional chemicals were studied as tracers of industrial and sewage pollution in addition to the above inferences. Nonylphenol, which is a raw material and biodegradation product of 
nonylphenol polyethoxylates (NPEs) (Giger et al., 1984; Rice et al., 2003; Cheng et al., 2006), could reveal, along with other contaminants, industrial pollution sources (Hong et al., 2009). NPEs have long been used in a wide variety of consumer products such as personal hygiene products, washing products and cleaners. Commercial products such as floor and surface cleaners also contain NPEs, and many industries (textile and pulp) used it as a surfactant or cleaner (Ferguson et al., 2001; Isobe et al., 2001; Sabik et al., 2003). Conversely, coprostanol and cholestanol are generally used as molecular markers to trace domestic pollution and especially human faecal pollution. Coprostanol is produced from the hydrogenation of cholesterol by bacteria in the human digestive system (Rosenfeld and Gallagher, 1964; Martin et al., 1973) and cholestanol is formed naturally in the environment by bacteria or the autochthonous production of phytosterols from high primary productivity; generally speaking, it is not of faecal origin (Martins et al., 2007). High levels of coprostanol have been found in human and mammalian faecal matter and domestic waste waters (Grimalt et al. 1990; Jeng et al., 1996; Hong et al., 2009). A ratio of $C_{\text {coprostanol }} /\left(C_{\text {cholestanol }}+C_{\text {coprostanol }}\right)[5 \beta /(5 \alpha+5 \beta)]$ was suggested (Grimalt et al. 1990) to cross-validate the pollution source. Ratios of $>0.7$ indicate urban sewage inputs, $<0.3$ indicate unpolluted sediments and 0.4-0.6 indicate a complex intermediary situation (Reeves and Patton, 2001).

Nonylphenol levels in sediments were higher, by at least a factor of 20 , in samples from the inner Masan Bay versus samples from the outer bay. Conversely, levels in Thau lagoon were fairly uniform except at sites TS11 and TS12, where concentrations were higher (by a factor of 8) than those found at the other sites. Coprostanol showed its highest concentration at site S12 in Masan Bay. However, inner bay levels (S5 and S8 sites) were higher than outer bay level (S20 and S21 sites) by a factor of 14. Contrary to the other chemical tracers, coprostanol 
concentrations were higher in the eastern part of Thau Lagoon. After comparison of all the study contaminants, sites S5, S12 and TS12 showed high levels of PCDD/Fs and PBDEs as well as NP, indicating both industrial and domestic pollution inputs.

The $5 \beta /(5 \alpha+5 \beta)$ ratio showed sites S12 and S5 in Masan Bay to have the highest values, although these values remained below 0.7 , hence implying a complex intermediary situation. The inner bay was shown to have higher values than outer bay, reflecting the extent of impact inside the bay. Sites TS14 and TS12 in Thau lagoon had the highest values, but these remained $<0.3$, indicating a low impact due to faecal pollution.

\section{Conclusions}

This joint research study on the levels and composition of persistent contaminants in two semienclosed water bodies in France and Korea revealed higher levels of all contaminants in Korea, hence reflecting the thrusting development of this country since 1960 s, coupled with the limited impact of existing regulations relating to chemicals. In addition, the measurement of industrial/domestic chemical markers and a sewage (faecal) marker in sediment samples helped identify possible point sources of pollution. This was especially clear in Masan Bay, where a sewage treatment plant has been identified as a primary source of pollution. The congener patterns showed differences in biota and sediment. Mussels showed a time-integrated accumulation pattern which was comparable at both sites, whereas sediments showed more specific contamination according to their location. Toxic equivalent calculations (TEQs) for PCDD/Fs in mussels from both France and Korea showed levels to be far lower than the maximum limit set by the European Commission for seafood safety. This study clearly points out that more rigorous monitoring is needed in Korea to help the authorities control and regulate the 
country's growing levels of chemical contamination.

\section{Acknowledgments}

KORDI and IFREMER would like to thank the 'Science and Technology Amicable Relationship (STAR)' program under which this joint study was conducted. This work was partially supported by grants-in-aid from Korea Ocean Research and Development Institute (PE9842A). The authors gratefully acknowledge the crews and participants who took part in the sampling cruises in Korea and France for their valuable help during sampling. 


\section{References}

Abad, E., Pérez, F., Llerena, J.J., Caixach, J., Rivera, J., 2003. Evidence of a specific pattern of polychlorinated dibenzo- $p$-dioxins and dibenzofurans in bivalves. Environ. Sci. Technol. 37, 5090-5096.

Baker, J.I., Hites, R.A., 2000. Is combustion the major source of polychlorinated dibenzo-pdioxins and dibenzofurans to the environment? A mass balance investigation. Environ. Sci. Technol. 34, 2879-2886.

Bayarri, S., Baldassarri, L.T., Iacovella, N., Ferrara, F., di Domenico, A., 2001. PCDDs, PCDFs, PCBs and DDE in edible marine species from the Adriatic Sea. Chemosphere 43, 601-610.

Booij, K., Zegers, B.N., Boon, J.P., 2002. Levels of some polybrominated diphenyl ether (PBDE) flame retardants along the Dutch coast as derived from their accumulation in SPMDs and blue mussels (Mytilus edulis). Chemosphere 46, 683-688.

Bordajandi, L.R., Matin, I., Abad, E., Rivera, J., Gonzalez, M.J., 2006. Organochlorine compounds (PCBs, PCDDs and PCDFs) in seafish and seafood from the Spanish Atlantic southwest coast. Chemosphere 64, 1450-1457.

Brzuzy, L.P., Hites, R.A., 1996. Global mass balance for polychlorinated dibenzo-p-dioxins and dibenzofurans. Environ. Sci. Technol. 30, 1797-1804.

Caixach, J., Calvo, M., Bartolomé, A., Palacios, O., Guerra, M., Abad, E., Rivera, J., 2007. Analysis of PBDEs, DL-PCBs and PCDD/Fs in caged mussels in the Western Mediterranean Sea. Mytilos Project. Organohalogen Compd. 69, 243-246.

Castro-Jimenez, J., Deviller, G., Mariani, G., Skejo, H., Umlauf, G., Guiot, N., Héas-Moisan, K., Léauté, F., Munschy, C., Tixier, C., Tronczyński, J., 2008. PCDD/F and PCB multi-media ambient concentrations, congener patterns and occurrence in a Mediterranean coastal lagoon (Etang de Thau, France). Environ. Pollut. 156(1), 123-135.

Cheng, C.Y., Liu, L.L., Ding, W.H., 2006. Occurrence and seasonal variation of alkylphenols in marine organisms from the coast of Taiwan. Chemosphere 65, 2152-2159.

Cischem. Com Co., Ltd., 2005. Report on the recent domestic and worldwide market demand of flame retardants and their regulation. Seoul. 339 p. (in Korean).

CITEPA, 2007. Inventaire des émissions de polluants atmosphériques en France. Séries sectorielles et analyse étendue. CITEPA/CORALIE/Format SECTEN, mise à jour février 2007, $291 \mathrm{p}$.

Dalla Valle, M.D., Marcomini, A., Sfriso, A., Sweetman, A.J., Jones, K.C., 2003. Estimation of $\mathrm{PCDD} / \mathrm{F}$ distribution and fluxes in the Venice Lagoon, Italy: combining measurement and modeling approaches. Chemosphere 51, 603-616.

EC No 199/2006. Commission Regulation (EC) No. 199/ 2006 of 3 February 2006 amending Regulation (EC) No 466/2001 setting maximum levels for certain contaminants in foodstuffs as regards dioxins and dioxin-like PCBs. Official Journal of the European Communities $\mathrm{L} 32 / 38$.

Ferguson, P.L., Iden, C.R., Brownawell, B.J., 2001. Distribution and fate of neutral alkylphenol 
ethoxylate metabolites in a sewage-impacted urban estuary. Environ. Sci. Technol. 35, 24282435.

Giger, W., Brunner, P.H., Schaffner, C., 1984. 4-Nonylphenol in sewage sludge: accumulation of toxic metabolites from nonionic surfactants. Science 225, 623-625.

Grimalt, J.O., Fernandez, P., Bayona, J.M., Albaiges, J., 1990. Assessment of fecal sterols and ketones as indicators of urban sewage inputs to coastal waters. Environ. Sci. Technol. 24, 357-363.

Hashimoto, S., Cho, H.-S., Morita, M., 1998. Polychlorinated dibenzo-p-dioxins and polychlorinated dibenzofurans in shellfishes from south coast of Korea. Chemosphere 37(5), 951-959.

Hashimoto, S., Horiguchi, T., Shibata, Y., Morita, M., 1999. Polychlorinated dibenzo-p-dioxins and dibenzofurans in invertebrate animals from a rural beach in Japan. Chemosphere 39(15), 2661-2669.

Hassanin, A, Lee, R.G.M., Johnston, A.E., Jones K.C., 2006. Reductions and changing patterns of ambient PCDD/Fs in the UK: Evidence and implications. Chemosphere 65, 530-539.

Hong, S.H.,Yim, U.H., Shim, W.J., Oh, J.R., Lee, I.S., 2003. Horizontal and vertical distribution of PCBs and chlorinated pesticides in sediments from Masan Bay, Korea. Marine Pollut. Bull. 46, 244-253.

Hong, S.H., Kannan, N., Yim, U.H., Li, D., Kim, M., Shim, W.J., 2009. Assessment of sediment contamination by persistent organic pollutants in Gyeonggi Bay, Korea. Toxicol. Environ., Health Sci. 1, 56-63.

Im, S.H., Kannan, K., Matsuda, M., Giesy, J.P., Wakimoto, T., 2002. Sources and distribution of polychlorinated dibenzo-p-dioxins and dibenzofurans in sediments from Masan Bay, Korea. Environ. Toxicol. Chem. 21 (2), 245-252.

Isobe, T., Nishiyama, H., Nakashima, A., Takada, H., 2001. Distribution and behavior of nonylphenol, octylphenol, and nonylphenol monoethoxylate in Tokyo metropolitan area: their association with aquatic particles and sedimentary distributions. Environ. Sci. Technol. $35,1041-1049$.

Isosaari, P., Pajunen, H., Vartiainen, T., 2002. PCDD/F and PCB history in dated sediments of a rural lake. Chemosphere 47, 575-583.

Jang, S.K., Shin, S.K., Kim, T.S., 2001. Analytical methods and characteristics of brominated flame retardants in environments. Anal. Sci. Technol. 14, 83A-108A (in Korean).

Jeng, W.L., Wang, J., Han, B.C., 1996. Coprostanol distribution in marine sediments off southwestern Taiwan. Environ. Pollut. 94, 47-52.

Johansson, I., Moisan, K., Guiot, N., Truquet, I., Munschy, C., Tronczyński, J., 2006. Polybrominated diphenyl ethers (PBDEs) in mussels from selected French coastal sites: 1981-2003. Chemosphere 64, 296-305.

Kannan, J., N., Yim, U.H., Hong, S.H., Shim, W.J., Li, D.H. and Oh. J.R., 2005. PYE [2-(1pyrenyl)ethyldimethysilylated silica] column HPLC and HR-GC- (micro) ECD in the accurate determination of toxic co-planar PCBs and Polybrominated diphenyl ethers 
(PBDEs). Bull. Korean Chem. Soc. 26(4), 529-536.

Kannan, N., Hong, S.H., Shim, W.J., Yim, U.H., 2007. A congener-specific survey for polychlorinated dibenzo-p-dioxins (PCDDs) and polychlorinated dibenzofurans (PCDFs) contamination in Masan Bay, Korea. Chemosphere 68, 1613-1622.

Khim, J.S., Kannan, K., Villineuve, D.L., Koh, C.H., Giesy, J.P, 1999. Characterization and distribution of trace organic contaminants in sediment from Masan Bay, Korea. 1. instrumental analysis. Environ. Sci. Technol. 33, 4199-4205.

Kierkegaard, A., Balk L., Tjärnlund, U., de Wit, C., Jansson, B., 1999. Dietary uptake and biological effects of decabromodiphenyl ether in rainbow trout (Oncorhynchus mykiss). Environ. Sci. Technol. 33, 1612-1617.

Knutzen, J., Bjerkeng, B., Naes, K., Schlabach, M., 2003. Polychlorinated dibenzofurans/dibenzo- $p$-dioxins (PCDF/PCDDs) and other dioxin-like substances in marine organisms from the Grenland fjords, S. Norway, 1975-2001: present contamination levels, trends and species specific accumulation of PCDF/PCDD congeners. Chemosphere 52, 745760 .

Koh, C.-H., Khim, J.S., Kannan, K., 2004. Polychlorinated dibenzo-p-dioxins (PCDDs), dibenzofurans (PCDFs), biphenyls (PCBs), and polycyclic aromatic hydrocarbons (PAHs) and 2,3,7,8-TCDD equivalents (TEQs) in sediment from the Hyeongsan River, Korea. Environ. Pollut. 132(3), 489-501.

Kueh, C.S.W., Lam, J.Y.C., 2008. Monitoring of toxic substances in the Hong Kong marine environment. Mar. Poll. Bullet. 57, 744-757.

Law, R.J, Herzke, D., Harrad, S., Morris, S., Bersuder, P., Allchin, C.R., 2008. Levels and trends of HBCD and BDEs in the European and Asian environments, with some information for other BFRs. Chemosphere 73, 223-241.

Law, R.LJ., Allchin, C.R., de Boer, J., Covaci, A., Herzke, D., Lepom, P., Morris, S., Tronczynski, J., de Wit, C., 2006. Levels and Trends of Brominated Flame Retardants in the European Environment. Chemosphere 64, 187-208.

Léauté, F., 2008. Biogéochimie des contaminants organiques HAP, PCB et pesticides organochlorés dans les sédiments de l'étang de Thau. Ph D thesis, Université Paris 6, Ifremer.

Li, D., Park, J., Oh, J.R., 2001. Silyl Derivatization of Alkylphenols, Chlorophenols, and Bisphenol A for Simultaneous GC/MS Determination. Anal. Chem. 73, 3089-3095.

Li, D., Park J., Oh J.R., 2003. Direct extraction of alkylphenols, chlorophenols and bisphenol A from acid-digested sediment suspension for simultaneous gas chromatographic-mass spectrometric analysis. J. Chromatog. A 1012: 207-214.

Li, D., Dong, M., Shim, W.J., Kannan, N., 2007. Application of pressurized fluid extraction technique in the gas chromatography-mass spectrometry determination of sterols from marine sediment samples. J. Chromatog. A 1160, 64-70.

Li, D., Dong, M., Shim, W.J., Yim, U.H., Hong, S.H., Kannan, N., 2008. Distribution characteristics of nonylphenolic chemicals in Masan Bay environments, Korea. Chemosphere $71,1162-1172$. 
Liu, Y., Zheng, G.J., Yu, H., Michael, M., Richardson, B.J., Lam, M.H.W., Lam, P.K.S., 2005. Polybrominated diphenyl ethers (PBDEs) in sediments and mussel tissues from Hong Kong marine waters. Mar. Pollut. Bull. 50, 1173-1184.

MacDonald, R.W., Ikonomou, M.G., Paton, D.W., 1998. Historical inputs of PCDDs, PCDFs, and PCBs to a British Columbia interior lake: the effect of environmental controls on pulp mill emissions. Environ. Sci. Technol. 32, 331-337.

Mai, B., Chen, S., Luo, X., Chen, L., Yang, Q., Sheng, G., Peng, P., Fu, J., Zeng, E.Y., 2005. Distribution of polybrominated diphenyl ethers in sediments of the Pearl River Delta and adjacent South China Sea. Environ. Sci. Technol. 39, 3521-3527.

Martin, M., Lam, P.K.S., Richardson, B.J., 2004. An Asian quandary: where have all of the PBDEs gone? Mar. Pollut. Bull. 49, 375-382.

Martin, W.J., Ravi Subbiah, M.T., Kottke, B.A., Birk, C.C., Naylor, M.C., 1973. Nature of fecal sterols and intestinal bacterial flora. Lipids 8, 208-215.

Martins, C.C., Fillmannc, G., Montone, R.C., 2007. Natural and Anthropogenic Sterols Inputs in Surface Sediments of Patos Lagoon, Brazil. J. Braz. Chem. Soc., 18, 106-115.

Moon, H-B., Ok, G., 2006. Dietary intake of PCDDs, PCDFs, DL-PCBs, due to the consumption of various marine organisms from Korea. Chemosphere 62, 1142-1152.

Moon, H.-B., Kannan, K., Lee, S.-J., Choi, M., 2007a. Polybrominated diphenyl ethers (PBDEs) in sediment and bivalves from Korean coastal waters. Chemosphere 66, 243-251.

Moon, H.-B., Kannan, K., Lee, S.-J., Choi, M., 2007b. Atmospheric deposition of polybrominated diphenyl ethers (PBDEs) in coastal areas in Korea. Chemosphere 66, 585593.

Moon, H.-B., Yoon, S.-P., Jung, R.-H., Choi, M., 2008. Wastewater treatment plants (WWTPs) as a source of sediment contamination by toxic organic pollutants and fecal sterols in a semienclosed bay in Korea. Chemosphere 73, 880-889.

Moon, H.-B., Choi, M., Choi, H.-G., Ok, G., Kannan K., 2009. Historical trends of PCDDs, PCDFs, dioxin-like PCBs and nonylphenols in dated sediment cores from a semi-enclosed bay in Korea: Tracking the sources. Chemosphere 75, 565-571.

Munschy, C., Guiot, N., Héas-Moisan, K., Tixier, Tronczyński, C., 2008. Polychlorinated dibenzo-p-dioxins and dibenzofurans ( $\mathrm{PCDD} / \mathrm{Fs}$ ) in marine mussels from French coasts: Levels, patterns and temporal trends from 1981 to 2005. Chemosphere, 73(6), 945-953.

Oh, J.R., Ikonomou, M.G., Fernandez, M.P., Hong, S.H., 2003. PCB and PCDD/F Totals, TEQs, and Congener Patterns in Korean Coastal Marine Environments, 1987, 1988, 1990, and 1996-1999. Arch. Environ. Contam. Toxicol. 44, 224-236.

Ohta, S., Nakao, T., Nishimura, H., Okumura, T., Aozasa, O., Miyata, H., 2002. Contamination levels of PBDEs, TBBPA, PCDDs/DFs, PBDDs/DFs and PXDDs/DFs in the environment of Japan. Organohalogen Compd. 57, 57-60.

Oros, D.R., Hoover, D., Rodigari, F., Crane, D., Sericano, J., 2005. Levels and distribution of polybrominated diphenyl ethers in water, surface sediments, and bivalves from the San Francisco estuary. Environ. Sci. Technol. 39, 33-41. 
Pan, J., Yang, Y.-L., Chen, D.-Z., Xu, Q., Tang, H., Li, Y., Nie, L.-M., Jiang, K., Xi, D.-L.. 2008. Distribution characteristics and source analysis of dioxins in sediments and mussels from Qingdao coastal sea. 70(9), 1699-1706.

Ramu, K, Kajiwara, N., Isobe, T., Takahashi, S., Kim, E.-Y., Min, B.-Y., We, S.-U., Tanabe, S., 2007. Spatial distribution and accumulation of brominated flame retardants, polychlorinated biphenyls and organochlorine pesticides in blue mussels (Mytilus edulis) from coastal waters of Korea. Environ. Pollut. 148, 562-569.

Reeves, A.D., Patton, D. 2001. Measuring Change in Sterol Input to Estuarine Sediments. Phys. Chem. Earth (B), 26, 753-757.

Rice, C.P., Isabelle, S.A., Jorge E, L.R., Link, E., Thoma, R., Fay, L., Altfater, D., Camp, M.J., 2003. Alkylphenol and alkylphenol-ethoxylates in carp, water, and sediment from the Cuyahoga River, Ohio. Environ. Sci. Technol. 37, 3747-3754.

Rosenfeld, R.S., Gallagher, T.F., 1964. Further studies of the biotransformation of cholesterol to coprostanol. Steroids 4, 515-520.

Sabik, H., Gagne', F., Blaise, C., Marcogliese, D.J., Jeannot, R., 2003. Occurrence of alkylphenol polyethoxylates in the St. Lawrence River and their bioconcentration by mussels (Elliptio complanata). Chemosphere. 51, 349-356.

Shim, W.J.,Oh, J.R., Kahng, S.H., Shim, J.H., Lee, S.H., Horizontal distribution of butyltins in surface sediments from an enclosed bay system, Korea. Environ. Pollut. 106, 351-357.

Souchu, P., Gasc, A., Cahet, G., Vaquer, A., Collos, Y., Deslous-Paoli, J.M., 1997. Biogeochemical composition of Mediterranean waters outside Thau lagoon. Estuar. Coast. Shelf Sci. 44, 275-284.

Wang, Y., Wang, T., Li, A., Fu, J., Wang, P., Zhang, Q., Jiang, G., 2008. Selection of bioindicators of polybrominated diphenyl ethers, polychlorinated biphenyls, and organochlorine pesticides in mollusks in the Chinese Bohai Sea. Environ. Sci. Technol., 42, 7159-7165.

Wang, Z., Ma, X., Lin, Z., Na, G., Yao, Z., 2009. Congener specific distribution of polyborrominated diphenyl ethers (PBDEs) in sediment and mussel (Mytilus edulis) of the Bo Sea, China. Chemosphere 74, 896-901.

Yim, U.H., Hong, S.H., Shim, W.J., Oh, J.R., Chang, M., 2005. Spatio-temporal distribution and characteristics of PAHs in sediments from Masan Bay, Korea. Mar. Pollut. Bull. 50, 319-326.

Zhu, J., Hirai, Y., Yu, G., Sakai, S.I., 2008. Levels of polychlorinated dibenzo-p-dioxins and dibenzofurans in China and chemometric analysis of potential emission sources. Chemosphere 70, 703-711. 
Table.1. Concentration ( $\mathrm{pg} \mathrm{g}^{-1} \mathrm{dw}$ or $\mathrm{ng} \mathrm{g}^{-1} \mathrm{dw}$ ) of polychlorinated dibenzo- $p$ - dioxins (PCDDs), polychlorinated dibenzofurans (PCDFs), polybrominated diphenylethers (PBDEs), nonylphenol, coprostanol and cholestanol in sediment samples from Masan Bay, Korea and Thau Lagoon, France.

\begin{tabular}{|c|c|c|c|c|c|c|c|c|c|c|c|}
\hline \multirow{2}{*}{ Compound } & \multicolumn{5}{|c|}{ Masan Bay } & \multicolumn{6}{|c|}{ Thau Lagoon } \\
\hline & S5 & S8 & $\mathrm{S} 12$ & $S 20$ & $S 21$ & TS14 & TS12 & TS11 & TS10 & TSC4 & TS2 \\
\hline \multicolumn{12}{|c|}{$P C D D / F s\left(p g g^{-1} d w\right)$} \\
\hline 2378-TCDF & 23 & 4.3 & 52 & 0.7 & 0.9 & 1.28 & 13 & 3.77 & 2.89 & 2.63 & 0.67 \\
\hline 12378-PeCDF & 18.8 & 8.1 & 116 & 1 & 1 & 0.44 & 5.05 & 1.62 & 1.25 & 1.2 & 0.27 \\
\hline 23478-PeCDF & 18.7 & 8.8 & 122 & 1.1 & 1.2 & 0.54 & 6.21 & 2.27 & 1.77 & 1.63 & 0.32 \\
\hline 123478-HxCDF & 23 & 16.9 & 252 & 2.2 & 2 & 0.62 & 6.57 & 1.98 & 1.54 & 1.71 & 0.42 \\
\hline 123678-HxCDF & 19.9 & 16.2 & 250 & 1.6 & 1.4 & 0.49 & 4.51 & 1.76 & 1.34 & 1.42 & 0.39 \\
\hline 234678-HxCDF & 18.6 & 17 & 260 & 1.8 & 1.6 & 0.74 & 6.16 & 2.26 & 1.99 & 1.84 & 0.48 \\
\hline 123789-HxCDF & 5.9 & 4.5 & 82 & 0.6 & 0.4 & 0.15 & 1.35 & 0.45 & 0.35 & 0.4 & 0.13 \\
\hline $\begin{array}{l}\text { 1234678- } \\
\text { HpCDF }\end{array}$ & 62 & 71 & 1035 & 9.6 & 8.6 & 3.24 & 60 & 11 & 8.42 & 9.17 & 2.17 \\
\hline $\begin{array}{l}\text { 1234789- } \\
\text { HpCDF }\end{array}$ & 7 & 9.2 & 161 & 1.3 & 1.1 & 0.18 & 3.99 & 0.72 & 0.53 & 0.73 & 0.19 \\
\hline OCDF & 55 & 68 & 765 & 17.7 & 12.6 & 2.6 & 99 & 11 & 6.9 & 8.9 & 1.7 \\
\hline 2378-TCDD & 2.9 & 1.1 & 5.9 & 0.2 & 0.2 & 0.06 & 1.15 & 0.12 & 0.09 & 0.11 & 0.03 \\
\hline 12378-PeCDD & 7.5 & 4.3 & 56 & 0.6 & 0.7 & 0.22 & 2.27 & 0.6 & 0.48 & 0.57 & 0.18 \\
\hline 123478-HxCDD & 3.6 & 2.8 & 36 & 0.4 & 0.5 & 0.2 & 2.08 & 0.57 & 0.43 & 0.57 & 0.13 \\
\hline 123678-HxCDD & 8.7 & 4.9 & 52 & 0.9 & 0.9 & 0.57 & 7.46 & 1.44 & 1.09 & 1.19 & 0.32 \\
\hline 123789-HxCDD & 7 & 4.6 & 50 & 0.8 & 1.3 & 0.8 & 5.54 & 1.43 & 1.07 & 1.21 & 0.31 \\
\hline $\begin{array}{l}\text { 1234678- } \\
\text { HpCDD }\end{array}$ & 61 & 49 & 413 & 14.1 & 13.7 & 9.46 & 162 & 23 & 16 & 18 & 3.73 \\
\hline OCDD & 415 & 429 & 976 & 262 & 212 & 78 & 1270 & 162 & 107 & 115 & 22 \\
\hline Sum PCDFs & 252 & 224 & 3095 & 38 & 31 & 10 & 206 & 37 & 27 & 30 & 6.74 \\
\hline Sum PCDDs & 506 & 496 & 1589 & 279 & 229 & 89 & 1451 & 189 & 126 & 137 & 27 \\
\hline Sum PCDD/Fs & 758 & 720 & 4684 & 317 & 260 & 99 & 1657 & 226 & 153 & 167 & 34 \\
\hline \multicolumn{12}{|c|}{ PBDEs $\left(p g g^{-1} d w\right)$} \\
\hline 28 & $<30$ & $<30$ & $<30$ & $<30$ & $<30$ & nd & nd & nd & nd & nd & nd \\
\hline 47 & 220 & $<30$ & 141 & 44 & 77 & nd & nd & nd & nd & nd & nd \\
\hline 49 & 36 & $<30$ & 121 & $<30$ & $<30$ & nd & nd & nd & nd & nd & nd \\
\hline 66 & $<30$ & $<30$ & $<30$ & $<30$ & $<30$ & nd & nd & nd & nd & nd & nd \\
\hline 77 & $<30$ & $<30$ & $<30$ & $<30$ & $<30$ & nd & nd & nd & nd & nd & nd \\
\hline 85 & $<30$ & $<30$ & $<30$ & $<30$ & $<30$ & nd & nd & nd & nd & nd & nd \\
\hline 99 & 375 & 49.5 & 319 & 30 & 63 & nd & nd & nd & nd & nd & nd \\
\hline 100 & $<30$ & $<30$ & $<30$ & $<30$ & $<30$ & nd & nd & nd & nd & nd & nd \\
\hline 138 & $<30$ & $<30$ & $<30$ & $<30$ & $<30$ & nd & nd & nd & nd & nd & nd \\
\hline 153 & 154 & $<30$ & 103 & $<30$ & $<30$ & nd & nd & nd & nd & nd & nd \\
\hline 154 & $<30$ & $<30$ & $<30$ & $<30$ & $<30$ & nd & nd & nd & nd & nd & nd \\
\hline 183 & 476 & 44.2 & $<30$ & 67 & 143 & nd & nd & nd & nd & nd & nd \\
\hline 209 & 23700 & 4770 & 12600 & 3310 & 6680 & nd & nd & nd & nd & nd & nd \\
\hline Sum PBDEs & 24961 & 4864 & 13284 & 3451 & 6963 & nd & nd & nd & nd & nd & nd \\
\hline \multicolumn{12}{|c|}{ Pollution tracers $\left(n g g^{-1} d w\right)$} \\
\hline Nonylphenol & 504 & 206 & 471 & 37 & 24 & 8.4 & 70 & 20 & 8.8 & 8.3 & $<2.8$ \\
\hline Coprostanol & 227 & 83.8 & 1100 & 29.9 & 16 & 815 & 767 & 427 & 21 & 61 & 279 \\
\hline Cholestanol & 364 & 501 & 1280 & 180 & 86 & 5430 & 6150 & 7210 & 4120 & 730 & 3040 \\
\hline $5 \beta /(5 \beta+5 \alpha)$ & 0.38 & 0.14 & 0.46 & 0.14 & 0.16 & 0.13 & 0.11 & 0.06 & 0.07 & 0.08 & 0.08 \\
\hline
\end{tabular}

nd: not detected, $5 \beta=\mathrm{C}_{\text {coprostanol }}, 5 \alpha=\mathrm{C}_{\text {cholestanol }}$ 
Table.2. Concentrations (pg g-1 dw or $\mathrm{ng} g-1 \mathrm{dw}$ ) of polychlorinated dibenzo-p-dioxins (PCDDs), polychlorinated dibenzofurans (PCDFs), polybrominated diphenyl ethers (PBDEs) and nonylphenol in mussel samples from Masan Bay, Korea and Thau Lagoon, France.

\begin{tabular}{|c|c|c|c|c|c|c|c|c|}
\hline \multirow[b]{2}{*}{ Compound } & \multicolumn{5}{|c|}{ Masan Bay } & \multicolumn{3}{|c|}{ Thau Lagoon } \\
\hline & M5 & M8 & M12 & M20 & M21 & TM2 & TM4 & TM1 \\
\hline \multicolumn{9}{|l|}{$P C D D / F s\left(p q q^{-1} d w\right)$} \\
\hline $2,3,7,8-T C D F$ & 2.8 & 1.8 & 1.7 & 0.6 & 1.1 & 4.0 & 3.5 & 2.7 \\
\hline $1,2,3,7,8-\mathrm{PeCDF}$ & 0.6 & 0.2 & 0.4 & 0.2 & 0.3 & 0.3 & 0.3 & 0.4 \\
\hline $2,3,4,7,8-P e C D F$ & 1.1 & 0.5 & 0.8 & 0.3 & 0.4 & 0.6 & 0.4 & 0.6 \\
\hline $1,2,3,4,7,8-\mathrm{HxCDF}$ & 0.3 & 0.1 & 0.2 & 0.1 & 0.2 & 0.1 & 0.1 & nd \\
\hline $1,2,3,6,7,8-\mathrm{HxCDF}$ & 0.4 & 0.2 & 0.2 & 0.2 & 0.2 & nd & 0.2 & nd \\
\hline $2,3,4,6,7,8-\mathrm{HxCDF}$ & 0.5 & 0.2 & 0.4 & 0.2 & 0.2 & 0.2 & 0.2 & 0.4 \\
\hline $1,2,3,7,8,9-\mathrm{HxCDF}$ & 0.1 & 0.1 & 0.1 & 0.1 & 0.1 & nd & $<0.06$ & 0.2 \\
\hline $1,2,3,4,6,7,8-\mathrm{HpCDF}$ & 1.1 & 0.4 & 0.7 & 0.4 & 0.5 & 0.4 & 0.5 & 1.0 \\
\hline $1,2,3,4,7,8,9-\mathrm{HpCDF}$ & 0.1 & nd & 0.1 & $\mathrm{nr}$ & nd & nd & $<0.07$ & 0.3 \\
\hline OCDF & 0.7 & 0.3 & 0.6 & 0.3 & 0.6 & 0.4 & 0.4 & 1.2 \\
\hline 2,3,7,8-TCDD & 0.2 & nd & 0.1 & nd & 0.1 & nd & 0.1 & nd \\
\hline $1,2,3,7,8-P e C D D$ & 0.5 & 0.3 & 0.4 & 0.1 & 0.2 & nd & nd & 0.2 \\
\hline $1,2,3,4,7,8-H x C D D$ & 0.2 & nd & 0.1 & $<0.07$ & 0.2 & nd & $<0.07$ & 0.3 \\
\hline $1,2,3,6,7,8-H x C D D$ & 0.3 & 0.1 & 0.2 & 0.1 & nd & 0.16 & $<0.06$ & 0.4 \\
\hline $1,2,3,7,8,9-\mathrm{H} \times C D D$ & 0.2 & nd & 0.2 & 0.1 & 0.2 & 0.17 & 0.1 & 0.5 \\
\hline $1,2,3,4,6,7,8-H p C D D$ & 1.3 & 0.5 & 0.8 & 0.6 & 0.8 & 1.57 & 1.6 & 2.9 \\
\hline OCDD & 4.2 & 1.5 & 2.8 & 2.5 & 4.7 & 6.44 & 5.4 & 10 \\
\hline Sum PCDFs & 7.7 & 3.8 & 5.2 & 2.4 & 3.6 & 6.0 & 5.6 & 6.8 \\
\hline Sum PCDDs & 6.9 & 2.4 & 4.6 & 3.4 & 6.2 & 8.3 & 7.2 & 14.3 \\
\hline Sum PCDD/Fs & 14.6 & 6.3 & 9.9 & 6.0 & 9.7 & 14.3 & 12.8 & 21.4 \\
\hline $\begin{array}{l}\mathrm{WHO}_{2005} \text {-TEQ } \\
\text { lowerbound }\end{array}$ & 0.272 & 0.139 & 0.213 & 0.075 & 0.109 & 0.143 & 0.128 & 0.181 \\
\hline \multicolumn{9}{|l|}{ PBDEs $\left(\mathrm{pg} \mathrm{g}^{-1} \mathrm{dw}\right)$} \\
\hline 28 & 468 & 266 & 366 & 104 & 85 & 263 & $<70$ & 165 \\
\hline 47 & 10300 & 3830 & 11500 & 841 & 648 & 635 & 368 & 307 \\
\hline 49 & 981 & 433 & 968 & 155 & 141 & 71 & $\mathrm{nr}$ & $<70$ \\
\hline 66 & 629 & 266 & 671 & $<70$ & $<70$ & $<70$ & $<70$ & $<70$ \\
\hline 77 & $<70$ & $<70$ & $<70$ & $<70$ & $<80$ & $<48$ & $\mathrm{nr}$ & $<56$ \\
\hline 85 & 515 & 163 & 608 & $<70$ & $<80$ & $<48$ & $<33$ & $<56$ \\
\hline 99 & 7040 & 2960 & 8340 & 489 & 332 & 283 & 177 & 151 \\
\hline 100 & 3600 & 1220 & 3990 & 255 & 171 & 189 & 81 & 136 \\
\hline 138 & $<70$ & $<70$ & $<70$ & $<70$ & $<80$ & $<48$ & $<33$ & $<56$ \\
\hline 153 & 291 & 144 & 387 & $<70$ & $<80$ & $<48$ & $<33$ & $<56$ \\
\hline 154 & 472 & 215 & 473 & $<70$ & $<80$ & $<48$ & $<33$ & $<56$ \\
\hline 183 & $<70$ & $<70$ & $<70$ & $<70$ & $<80$ & $<48$ & $<33$ & $<56$ \\
\hline 209 & $<100$ & $<100$ & $<100$ & $<100$ & $<100$ & $<100$ & $<100$ & $<100$ \\
\hline Sum PBDEs & 24296 & 9497 & 27303 & 1844 & 1377 & 1441 & 626 & 759 \\
\hline Nonylphenol ( $\mathrm{ng} \mathrm{g}^{-1} \mathrm{dw}$ ) & 289 & 170 & 111 & 77 & 51 & 32 & 42 & 40 \\
\hline
\end{tabular}




\section{Figure legend}

\section{Fig. 1.}

a. Map of Masan Bay showing the sampling sites. Both sediment and mussel were collected at the same site. Thus, M5, M8, M12, M20 and M21 indicate mussel samples, and S5, S8, S12, S20 and S21 indicate sediment samples. Point sources of contamination such as STP (Sewage Treatment Plant) and Urban Industrial Complex are indicated on the map. Big cities on the shore such as Masan, Changwon and Chinhae are indicated as well.

b. Map of Thau Lagoon in the Gulf of Lions, Mediterranean Sea showing the sampling sites. TM1, TM2 and TM4 indicate sites where mussel was collected. TS2, TSC4, TS10, TS11, TS12 and TS14 indicate sites where sediment was sampled.

\section{Fig. 2.}

Isomeric composition of PCDDs and PCDFs in sediment and mussel from Masan Bay and Thau lagoon.

\section{Fig. 3.}

Principal component analysis (a) score plot and (b) loading plot of the PCDD/Fs congener patterns and NP in sediments and mussels from Masan Bay and Thau lagoon. Individual congener concentrations are normalized to total PCDD/Fs. 
a.

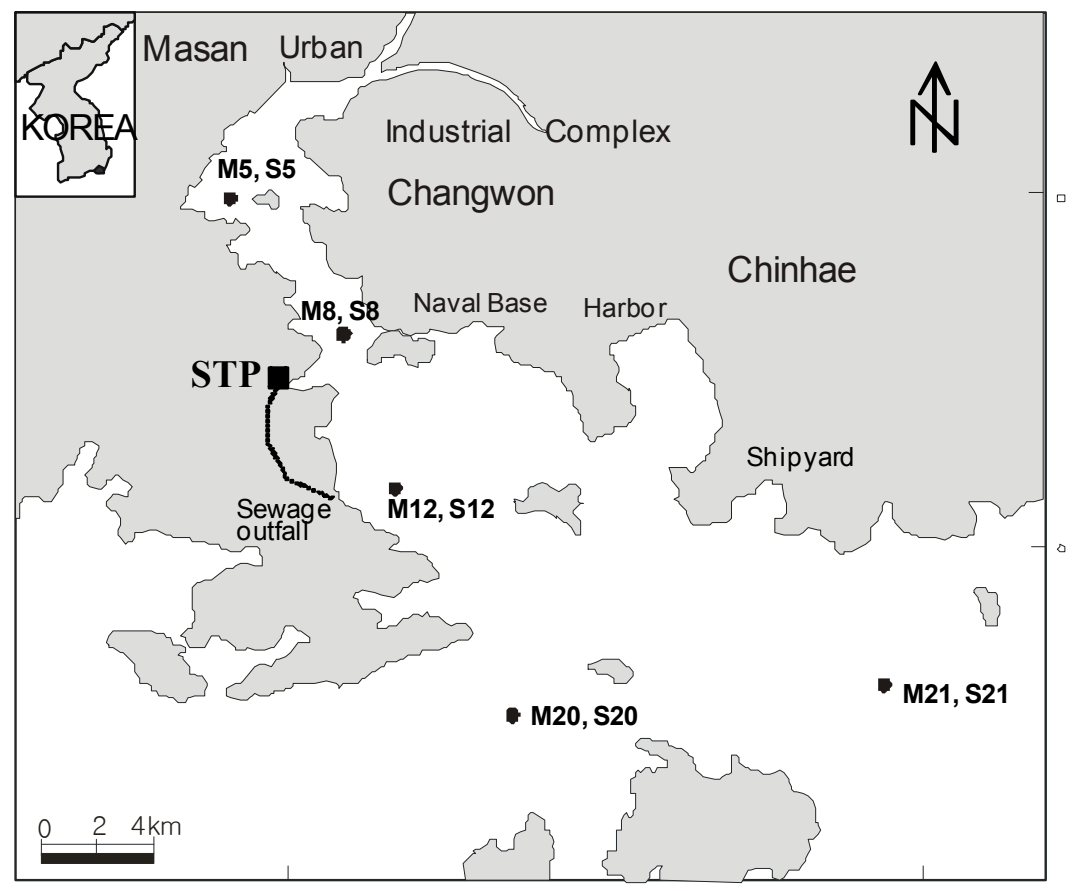

$128^{\circ} 35^{\prime} \mathrm{E}$

$128^{\circ} 45^{\prime}$

b.

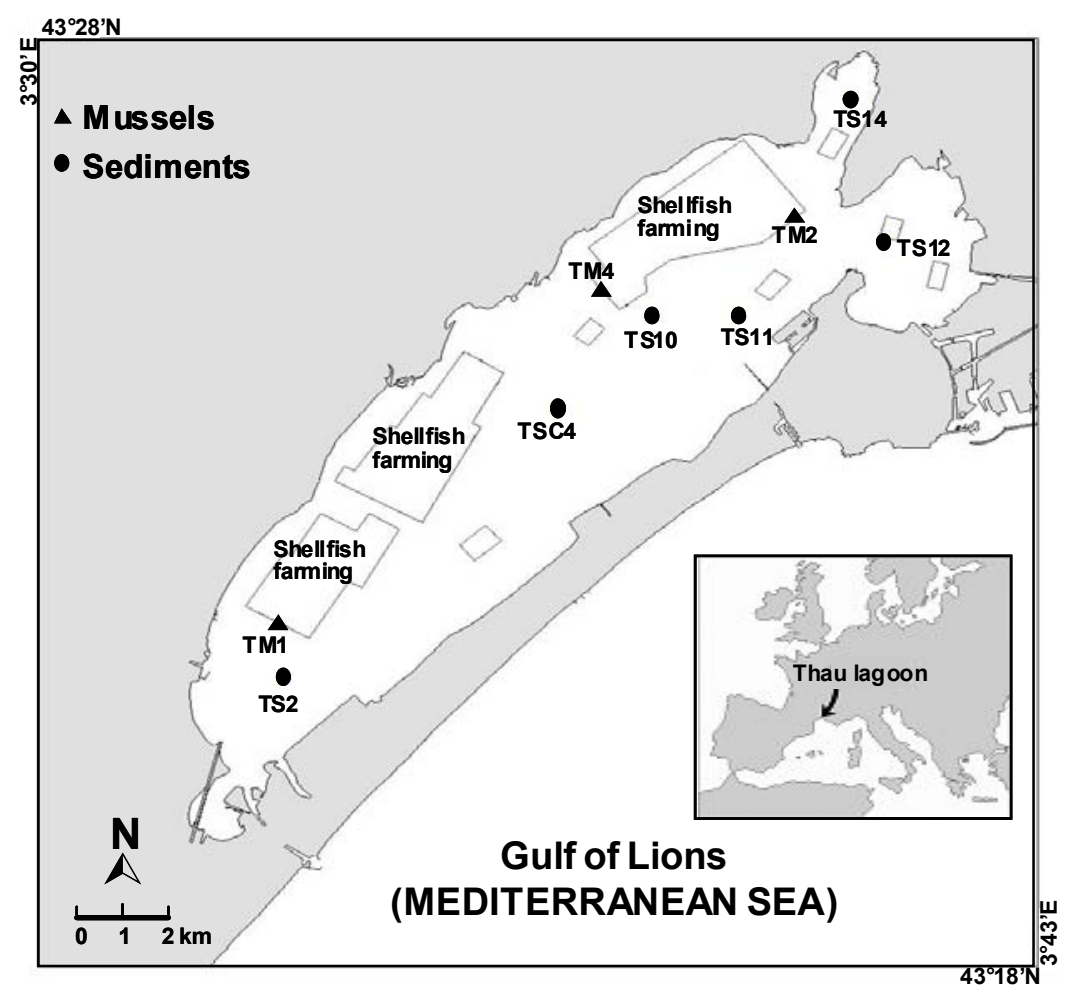

Fig. 1 

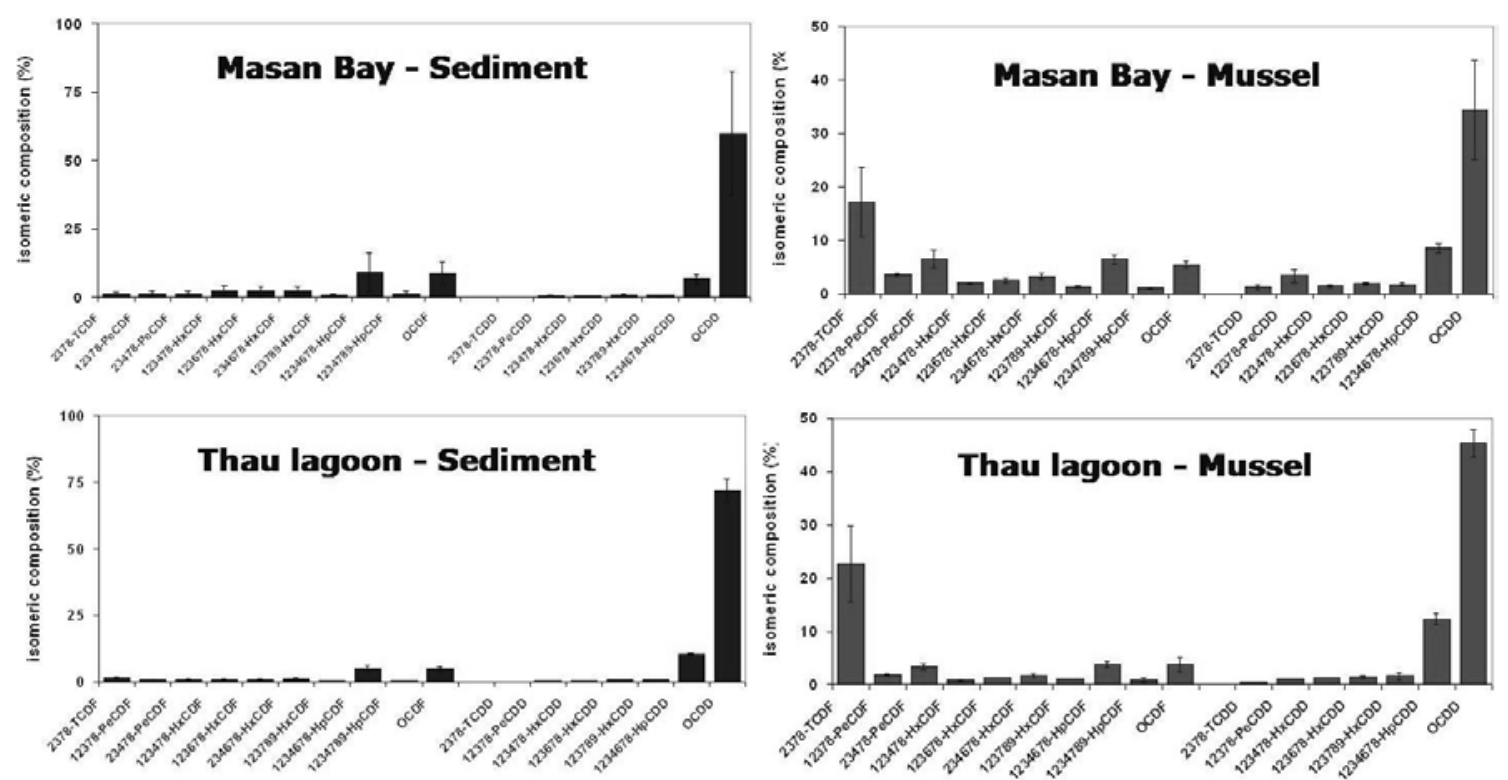

Fig. 2 
a.

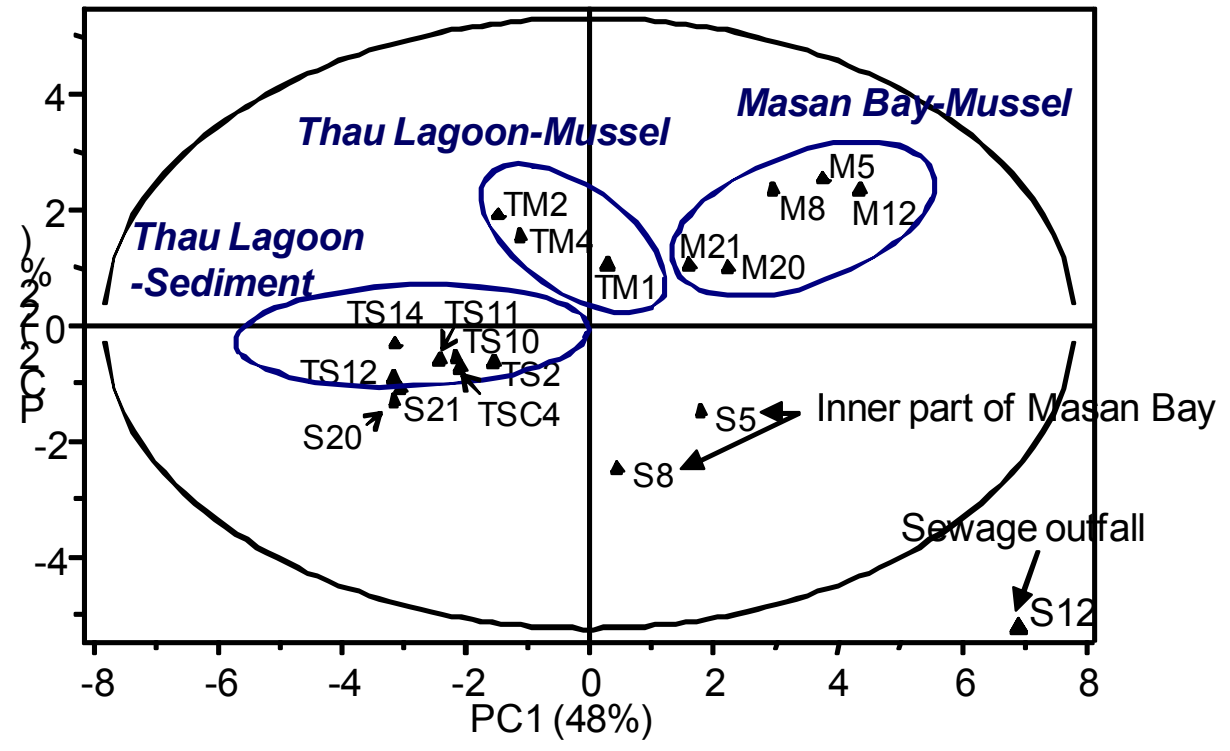

b.

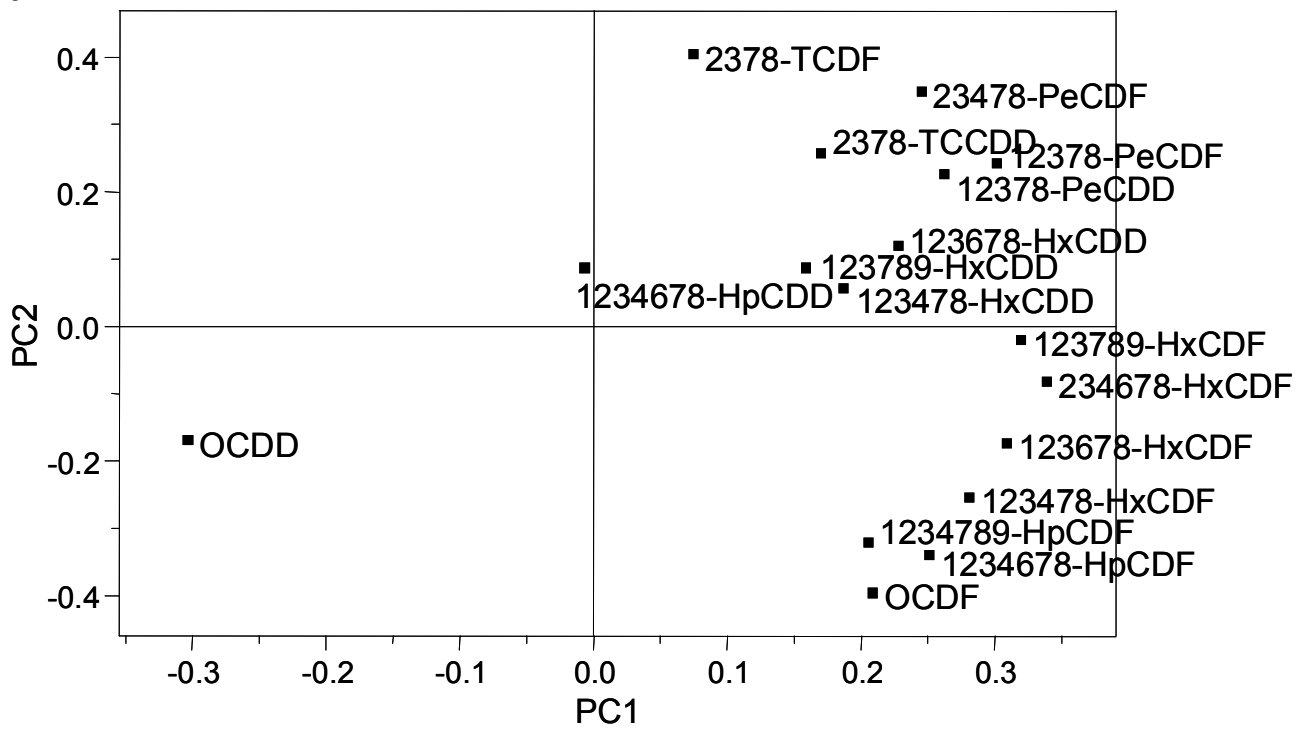

Fig. 3 